\title{
Psychosocial and Criminological Environment Related to Pedocriminality: Nine Cases of Children Rape Reported in Abidjan (Côte d'Ivoire)
}

\author{
Traoré Brahim Samuel ${ }^{1,}$ *, Aka Rita Ahou ${ }^{1}$, Kouamé Yapo Guy Serge ${ }^{3}$, \\ Zikéto Bla Désirée Sandrine ${ }^{2}$, N'Degbeu N'dri Lopez ${ }^{2}$, Yéo-Ténéna Yessonguilana Jean-Marie ${ }^{1}$ \\ ${ }^{1}$ Medical Sciences Training and Research Unit, Félix Houphouët Boigny University, Abidjan, Ivory Coast \\ ${ }^{2}$ Addiction and Mental Hygiene Service, National Institute of Public Health, Abidjan, Ivory Coast \\ ${ }^{3}$ Pediatric Surgery Department, Yopougon University Teaching Hospital, Abidjan, Ivory Coast
}

Email address:

samygrande@live.fr (T. B. Samuel), rita_aka@yahoo.fr (A. R. Ahou), yapokoua@yahoo.fr (K. Y. G. Serge), zikesand123@gmail.com (Z. B. D. Sandrine),ndegbeundrilopez2017@gmail.com (N. N. Lopez),

ouandete@gmail.com (Yeo-Tenena Y. Jean-marie)

${ }^{*}$ Corresponding author

\section{To cite this article:}

Traoré Brahim Samuel, Aka Rita Ahou, Kouamé Yapo Guy Serge, Zikéto Bla Désirée Sandrine, N’Degbeu N'dri Lopez, Yéo-Ténéna Yessonguilana Jean-Marie. Psychosocial and Criminological Environment Related to Pedocriminality: Nine Cases of Children Rape Reported in Abidjan (Côte d'Ivoire). American Journal of Psychiatry and Neuroscience. Vol. 9, No. 3, 2021, pp. 136-142.

doi: 10.11648/j.ajpn.20210903.21

Received: July 16, 2021; Accepted: August 10, 2021; Published: September 4, 2021

\begin{abstract}
Child rape in Abidjan is increasingly mobilizing socio-judicial systems. But psychopathological disorders and associated psychosocial disturbances are sometimes neglected in the process of care. Studying the impact of these sexual crimes on the psychosocial environment of the victims led us to carry out a qualitative study from 2019 to 2020 in two Pediatric Surgery Departments in Abidjan. Based on a purposive sampling strategy, nine (09) victims were selected and their cases are presented under the form of monographs. They were girls aged from 15 months to 7 years. Almost all of them were victims of premeditated rape of proximity. The modus operandi of the rapes followed four phases: attract of the victim, sending to a predatory site, raping and finally release of the victim. The injuries diagnosis indicated tears and perineal damage, evidence of violent vaginal insertive intercourse and / or requiring a forced penetrative gesture. From 06 of the victims, psycho-traumatic disorders were observed and symptoms of vicarious trauma from 04 groups of helpers, associated with a disruption of family dynamics (relocation, conflicts and separation). However, conventional psychological follow-up has only been offered to 02 out of the 09 patients. Child rape is an archaic pathology of civilizations which must include psychosocial care for victims and their caregivers preceded by clinical clarification and rigorous psycho-criminological study.
\end{abstract}

Keywords: Child Crime, Child Rape, Psychotrauma, Family Dynamics

\section{Introduction}

Rape refers to a contact of an attractive weak target victim with a rapist which will be subjected to a strategic analysis of the risks and profits, but rationally limited [1]. As for children, the skills to resists and the power of judgement are weak, if not non-existent to escape from rape or resist any measure of coercion unlike adults. As such the following concern can be raised: are children regular targets for sexual abusers? Indeed, even if rape appears as inherent to human civilisation, children rape was unknown in the collective psyche of some societies. In African society for example, children are perceived as community heritage. As such, they benefit from huge emotional investments that prevent them from sexual abuses from sensible adults.

Many international studies have laid the emphasis upon children sexual abuses by adults. The study related to Impact des violences sexuelles de l'enfance à l'âge adulte, carried out in France [2], has pointed out that $81 \%$ of the 1,214 
interviewees have experienced sexual violence before 18 years old, $51 \%$ before 11 years old and $21 \%$ before 6 years old. In Côte d'Ivoire, according to a report by the Human Rights Division (DDH) of the United Nations Operation in Côte d'Ivoire (UNCI) [3] concerning the rapes and attempted rapes from 2012 to 2015, seventy-seven percent (77\%) of victims registered by $\mathrm{HRD}$, namely 761, are children between the ages of 2 and 17.

Since that period the ivorian socio-legal services have addressed an increasing number of children rapes, the seriousness of the situation and families distresses. When it is non-lethal rape [4], the main objective of the families and the medical staff remains the curing of the injury, hoping an adintegrum reconstruction. Unfortunately, psychopathological disorders and the impact of rapes on the victims' psychosocial environment are ones of the most neglected aspects of their health care. As such, a clinical and psychocriminological study is required for a better psycho-social management of the different cases. Because several studies have shown that sexual assault against children has specific criminal dynamics and that it is not appropriate to apply knowledge about adult victims by analogy $[5,6]$.

To reach this objective, three main issues were raised: first, what are the methods used by rapists to abuse their young victims? Then, what are the psychological impacts on their victims? Finally, what are the impacts of these abuses on the relatives?

\section{Materials and Methods}

This survey is a cross-sectional study which includes a qualitative component. It occurred from August 1, 2019 to October 31, 2020 in the Pediatric Surgery Departments of the Yopougon and Treichville University Teaching Hospitals in Abidjan (Côte d'Ivoire). The study population involves twenty five (25) female patients. Paediatric raped patients which have been treated in one of the above service and benefited from family caregivers were included in the study. Lethal rape victims were not included. Based on a purposive sampling method which more illustrates the clinical realities, nine (09) patients were selected for the reading of this monograph.

\section{Results}

1) Monograph 1: "candies as a bail to trap which ends by a rape"

This is a story of a 5 five year children (V1) living in one of the houses arranged around a common interior courtyard. She was suffering from pelvic pain and vaginal bleeding just three hours (03) after her abuses. A perineal repair was performed. Following her admittance to hospital, V1 not only endured insomnia but she refused to feed herself. Family caregivers (mother and father) have reported an emotional shock as a result of the sexual violence and a sense of guilt. As a consequence, the family relocated. The perpetrator was a young man who offered the victim some sweets while she was playing with her friends. She was raped in a pedestrian alley about $2 \mathrm{~km}$ from the family home.

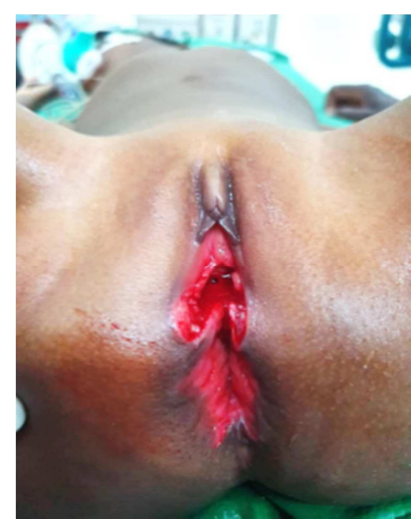

Figure 1. 3rd degree perineal tear.

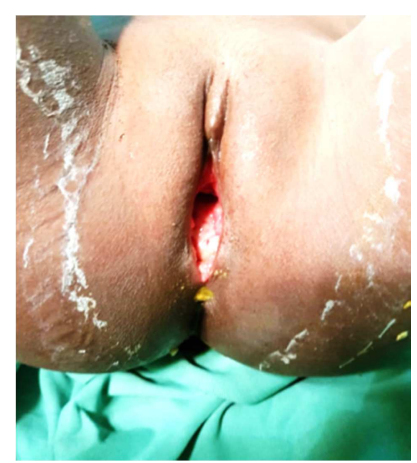

Figure 2. Hymen and vulvar area rupture without recto vaginal link.

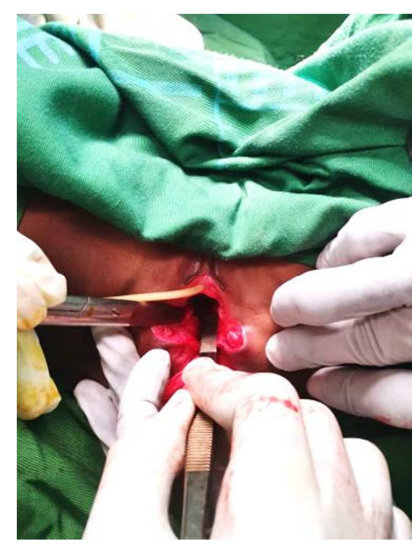

Figure 3. Checking up of the injuries in the surgical unit.

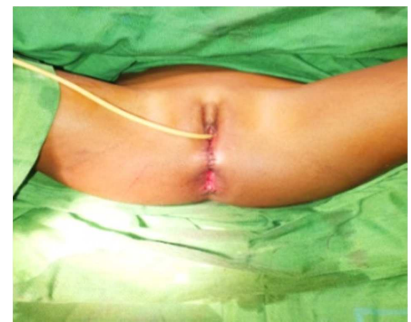

Figure 4. Aspect of the perineum.

2) Monograph 2: "a young girl body blemished, a soul to purify"

The second victim was a seven $(07)$ years old child when 
was abused. She was living in a house arranged around a common interior courtyard with her parents. She consulted for pelvic pain and vaginal bleeding in the Department of Pediatric Surgery. The gynaecological examination revealed a tear of not only the vagina posterior wall, but also that of the anal and vulvar septum with an abrasion of the anal mucous membrane which necessitated a perineal repair. Feeling of shame and avoidance behaviors were noticed during the stay at the hospital. As for the parents, especially the mother, she developed a sense of guilt and fear, which was the reason of the family relocation and a traditional purification ritual was organization. The perpetrator was a young adult. After having asked the child who was playing with her gamemates to join him, he took her to the bush, 500 meters from the family house. He theatened to kill her if she dare shout for help before raping her.

3) Monograph 3: "she was not even allowed to shout it out"

This is a five (05) years old girl (V3) story that was living with her parents. She consulted for vulvar bleeding. A vulvovaginal injury with a perforation of the Douglas was diagnosed. This damage has required vulvo-vaginal and vulvar reparations. During her hospitilization period, (V3) has shown a sign of social isolation. A sense of responsibility and parental fealure were developed by the parents. The family relocated and this situation has become a source of conflict related to the supervision of the child. The perpetrator was a young adult who asked $V 3$ to follow him when she was playing behind the family house. Then, he sexually abused her by threatened her not to shout.

4) Monograph 4: "rape as a second intention"

It is about a seven (07) year old girl when the event happened. "V4" was living in a common yard with her parents. She was taken to the Pediatric Surgery emergency room with vaginal bleeding. She was diagnosed with a tear of the ano-vulvar facet and posterior wall of the vagina and she underwent perineal repair. No symptoms related to psychopathological disorder were found. But the parents presented palpitations with unexplained fear and isolation. The family relocated following this incidence. The perpetrator was an adult who has no connection with the victim. She was kidnapped during nighttime burglary and raped near the family home.

5) Monograph 5: "The neighbor, my executioner"

This is about three (03) years old child who was living with her grandmother. They were squatting an unfinished house. The little girl, for the purpose of this study, will be called "V5", was brought to the pediatric surgery emergency room when she was diagnosed with vaginal bleeding. Clinical examination revealed an ano-vulvovaginal wound with a tear of the rectovaginal septum. A colostomy with rectovaginoplasty was performed. No psychological symptoms were oberved, but the grandmother complained of palpitations, unexplained crying, and isolation, which led to the family relocation. The perpetrator of the sexual abuse was a young adult brother of the family neighbor. The latter raped her a few meters from the house as she went out to urinate as her grandmother used to do. This happened at around 5:30 am. The grandmother didn't realize that she went out.

6) Monograph 6: "An innocent girl kidnapped and raped"

This is the story of a seven (07) year old girl, living with her parents in a common yard, taken to the pediatric surgery emergency room about four (04) hours after the finding of genital bleeding. Clinical examination showed perineal collapse which required perineal repair. The aftermath of hospitalization was marked by the onset of night terror attacks, refusal to feed oneself and social isolation. Although family dynamics remained stable after the assault, the family relocated. The perpetrator of the rape is said to be an adult, unknown to the victim. She was kidnapped when she were buying a telephone communication credit. She was driven to 500 meters from the family house and raped.

7) Monograph 7: "In the footsteps of my grandmother I met a child rapist"

The victim was a three (03) year old girl, living in a common yard with her grandmother. She was sent to the pediatric surgery emergency service following the observation of genital bleeding. She was diagnosed witn a perineal dilapidation (opening of the perineum going from the anal margin to the vagina, a tear from the entrance of the vagina to the muscular plane and a right lateral longitudinal tear of the vaginal mucosa from the entrance of the vagina. vagina to the muscular plane). Perineal and genital reconstruction with protective colostomy was performed. Night terrors attacks and isolation have been observed since the rape and symptoms of acute stress have been observed from her parents. As for the grandmother, she developed a feeling of guilt. The family dynamic was disrupted by conflicts which resulted in the separation of the parents of the victim. The perpetrator of the rape was an unknown man who has no connection with the victim. The rape took place in an unfinished house where he led his lost victim into the night as she looking for her grandmother. V7 was then thrown into a brush.

8) Monograph 8: "Taken from sleepbed to face an horror"

V8 is a five (05) year old girl living in a common yard with her parents. She was sent to the emergency pediatric surgery for vaginal bleeding observed a few hours earlier. The diagnosis of third degree perineal tear was retained. The victim received perineal repair from a bi-tubular colostomy with a skin bridge. No psychopathological disorder was noticed. On the other hand, the parents presented palpitations, a trouble disorder with isolation behavior. They eventually relocated. The perpetrator is said to be an adult, unknown to the victim, who allegedly kidnapped her from her sleeping bed where she was sleeping with her older sisters. He dragged her to an unfinished house far from the family home to rape her.

9) Monograph 9: "abduction and rape of a baby girl"

This is the story of V9 who is the youngest victim. She was fifteen (15) months old and was living in a residential dormitory with her parents. She was taken to the pediatric surgery department for vulvar bleeding. A perineovaginal wound extending from the posterior fourchette and $1 \mathrm{~cm}$ from the posterior wall of the vagina with blood clots was 
diagnosed. These lesions required vaginal repair. In the aftermath of the hospitalization, the victim's parents reported behavioral disturbances such as fear of strangers, incessant crying and irritability. Concerning the parents, they reported moderate trouble disorder, but the family dynamics remained stable. The perpetrator of the sexual abuse was a young adult who was the boyfriend of V9's nanny. The girl was kidnapped for ransom. The sexual abuse took place at latter home.

Finally, it should be remembered that among the 9 victims, psychological care was only offered to V3 and V5.

\section{Discussion}

The nine victims were between one (01) and seven (07) years old. For B. Lormeau et C. Rey-Salmon [7], child sexual abuse is defined as "any involvement of a child or adolescent in sexual process that he or she is unable to understand, which is inappropriate as regard her/his age and psychosexual development, by consent or violence and violate social taboos". The victims in our study were mostly not able make the difference between sexual and physical abuses. They were therefore unable to defend themselves or escape from the perpetrators. We note that 05 victims (V1; $\mathrm{V} 3$; V5; V7; V8) out of the 09 are between 03 and 05 years old. By re-examining Erickson's theoretical approach to psychosocial development [8], we can understand the repetition of children sexual abuses at this age even if it is not a common practice. During the third stage (3-5 years), it is reported that after the empowerment stage, children build social interactions outside the family setting and begin to develop their power and control over the world through game. Therefore, one can understand why they are localised in playgrounds by their abusers. From another point of view, it is admitted in some african societies that the acquisition of certain occult or financial powers requires a ritual sexual intercourse with a being of a "pure" soul, namely a child or young virgin.

Whether it is ritualistic rape or of another type, the sample population is exclusively composed of female children. An analysis carried out by the WHO in 2004 found a global prevalence of sexual violence against children involves aproximatively $27 \%$ among girls and $14 \%$ among boys [9]. The perpetrators of sexual violence against children sometimes have specific characteristics compared to those who attack women, even if pedocriminality is very often part of the continuum of violence and domination against women. Failing to be able to maintain a heteroeroticism or otherwise this domination against women, they only abuse of the weakest or more vulnerable of the same sex [10].

The vulnerability of these victims is not only linked to their young age. It is obviously related to their type of habitat they live in. Living in impoverished neighborhoods with common courtyards makes rapists easily identify their targeted children. These insecured poor environments (narrow sidewalks, damaged borders, lack of sufficient lighting, bushes closed to the habitats, unfinished houses, insecured playgrounds) offer more opportunities for rapists to reach their goals. This is a typical case of 05 victims included in our study who lived in "common yards". The urban "common courtyard" is a habitat reproducing the organization of the village space. Taking the example of the city of Abidjan, Touré et al. [11] specifies that "intentional assault and battery is frequent in popular housing areas dominated by common courtyards and promiscuity". This promiscuity actually enshrines another risk factor for child aggression mentioned above: proximity.

From our study, four-phase operating mode related to the rapes can be pointed out: attracting the victim attention (by using bait, intimidation, verbal force, abuse of the state of weakness or abduction). This trust in unknown people is the result of immaturity, weak analysis capacity and the satisfaction of personal needs. In the first stage of Erikson's psychosocial development (0-18 months), children learn whether or not to trust others [5]. Trust is closely related to attachment, relationship management, expectation from others to meet his or her personal needs. Due to their poor social skills, many child sexual abusers are comfortable in a relationship with a child who is passive, psychologically dependent and easy to handle [12]. These are the characteristics that some abusers observe. The more a child shares these attributes the more he appears as a real prey [13, 14]. Most child sexual abusers create a context to overcome children's resistance (...). These means are most often noncoercive [12-16]. But in some cases they have sometimes been coercive. This may include: use of varying degrees of force, psychological intimidation, threats and brutalization and kidnapping. The second phase is the sendind of the victim to a predation site. In fact, six (06) of the nine (09) victims were abused in perimeters generally greater than 500 $\mathrm{m}$ from their family home. Then, three (03) of the rapes occurred in the predation site; namely in the brush or unfinished houses. These unsecured sites are used by delinquents and other criminals for their crimes. Finally, the relaxation of the victim is the only passive phase of the process.

The modus operandi used by raised the issue of the crimes with intent. In this regard, a large majority (between $70 \%$ and $80 \%$ ) of sexual abuses against children is thought to be planned. This is against the thesis of sexual urges and lack of control from the aggressors [13]. The sexual abuses of the victims V1, V2, V3, V6 and V8 reflect this logic since the rapes are planned and follow elaborate strategies which have been developed in the four phases mentioned in the previous pages. However as for the cases V4, V5 and V7 the sexual abuses do not seem to have been planned. They were linked to circumstances. Nevertheless the selection of favorable situations rather than precise victims may refer to what Rossmo (2000) called premeditated opportunism [17]

In all three cases, the perpetrator took advantage of the child lost or the rape was associated to another crime. They could be seen as circumstantial rapists [18].

Whatever its nature, the description and / or identification of the suspects or perpetrators of these sexual abuses required 
the testimony of the close family due to the age of the victims Thus, the summary profile of sexual aggressors in our study is that of a young adult male. Despite a few exceptions, the perpetrators of rape are almost always men. These men are quite young (about 30 years old), slightly older in family rapes (especially of grandfathers). On the contrary, they are very young adults or even minors in the cases of rapes committed by family members (brothers, cousins) or in gang rapes [19].

Based on the typology of child sexual abusers by Groth, two of the types he described can be found in our series of authors. The fixed, when the aggressor has a persistent and compulsive attraction to children and the regressed, which refers to the individual who is involved in sexual abuses due to specific situations and on the basis of external stressors [20]. The second type is similar to the circumstantial rapist as in case V4, where the rape is carried out during a burglary. A final rapist profile can be considered in our context: that of the "ritualistic rapist" who performs a mystical ritual as initially indicated.

The diagnosis of the damage reveals the nature and violence of the aggression. Most of the cases were vaginal penetration with tears or perineal sagging. As for V2 and V5, they seem to have endured anal penetration due the feature of this organ. In every case, these are insertive sexual act that is either violent or required a forced penetrative sex given the immaturity of the ano-genital organs of the victims. Due to the extent and the seriousness of body injuries, one can set up a link with the rapists who shift their aggressive impulses or rapists characterized by the violence of their behaviour described by André McKibben [21].

Moreover, these genital traumas have psychotraumaticimpacts. The review of the psychochological symptoms observed reveals: sleep disorders, refusal to feed onself, attitudes of embarrassment, isolation, avoidance behaviors, night sleep terrors, fear of strangers, permanent crying and irritability. Post-Traumatic Stress Disorder (PTSD) is the main psychopathological consequence resulting from exposure to a major event, such as those threatening the subject's life or integrity. Knowledge related to children has improved a lot in recent years, especially clinically [22].

We are now aware that children can endure PTSD, even very young children. This is not the result of shortcomings or inability of parents as for aduct case, but the consequence of catastrophic event which is essential for the diagnosis. It represents the most common complication in cases of physical or sexual abuse (...). A number of semological features and developments depict the PTSD endured by young patients (...). By the age of 5, we rather find nightmares dominated by nonspecific issue, without clear content or night terrors. Neurovegetative hyperactivity is also found. It covers a set of symptoms that appeared during the trauma: difficulty to sleep, waiking up multiple times at night, irritability (...) [1]. As for the particular case of our study, the symptoms of the temporarity are not well defined. As such, we can only focus on the victims' psychotrauma (V2, V6 and V7.). However, the other victims such as V1, V3 and V9 show symptoms that cannot be categorized as a specific psychopathological disorder. It may be adjustment disorder or "other disorder related to trauma or stressors" from DSM.

As much as these child victims of rape, their family carers are likely to present psychopathological disorders. The news is a source of trauma for the parent for they can even believe the situation endured by their offsprings. For the parents of abused children, the consequences are mainly related to emotion and behaviour. Some parents will experience a deep emotional wound after seeing their child. Others will experience a feeling of doubt or denial as well as significant psychological stress [23].

After a psychological evaluation, the consequences experienced by the parents can be classified as vicarious (or secondary) trauma, since some correspond to the symptoms of PTSD [24]. Vicarious trauma involves symptoms such as confusion, a feeling of insecurity or vulnerability, a feeling of helplessness or injustice. The relocations observed in all the families of the victims support this feeling of insecurity. On the other hand, these relocations can be linked to avoidance behavior, which reinforces the hypothesis of psychotrauma. Again, we could only mention Acute Stress Disorder (ASD), as the symptoms were not assessed on a long run in this study. Other psychological consequences can also be observed. Thus, the latter may feel a sense of helplessness regarding their child's suffering; they have had the feeling of being a bad parent (...). In addition, the child's parents may feel not only anger when they meet the abuser but develop a feeling of guilt for not having been able to protect their children. They also become hypervigilant and they set some restrictions to prevent any other sexual abuses [23]. And in this respect, the parents or in some cases the family carers of $\mathrm{V} 1, \mathrm{~V} 2, \mathrm{~V} 3$ and V7 have reported symptoms of psychological distress and a feeling of guilt.

Parents who learn that their children have been sexually abused can also experience social, family and marital life issues. Since two individuals form a conjugal entity, reactions are often not synchronized. Communication issues and marital conflicts can then become important, in addition to difficulties in terms of sexuality [23]. V7 is a perfect illustration of this description; especially since after several conflicts following the rape, the parents divorced.

When a traumatic event occurs, various parental functions can be disrupted. These functions involve the qualities of interaction of the parent with his child. Romano [25] shows how the three parental functions of protection, understanding and affection / appreciation can be achieved. The dysfunction of these three parental functions depends on the parents' previously existing resources. These parental resources involves the psychological state of each of the parents and the parental couple, family beliefs, family dynamics, social support and the mode of communication before the event. The disruption of family dynamics (conflicts and separation) observed in cases V3 and V7 confirms the importance of considering the global approach in the care of victims.

Finally, the search for an alternative to the absence of 
conventional psychological care was noted as for the victim V2. A purificatory rite was performed at home. Aware that the prohibition of rape does not prevent sex abuse, various african cultural groups had instituted rites of reparation or purification of the victims. Lévy Bruhl asserts that the stain resulting from a sexual transgression is a social stain and not a stain of blood, because the violation of a sexual prohibition is an "offense against the organization on which community life is based" [26]. The transgression of the taboo undermines the security of oneself and of the group (...). There is in the world of taboo a "system of restoration of order" which provides for rituals to appeal to the grace of ancestors, founding beings, guarantors of taboos (...). this system of restoration of the other allows the defiled individual to redeem himself and reintegrate into the community. Indeed, whether the person exposes himself or whether he is forced to expose himself to defilement, he is nevertheless defiled and must suffer the consequences (illness, bad luck, drought, conflicts, deaths...). Empowerment without discrimination underlies the fact that any person involved in is seen as a guilty even if he or she does not willingly participate in. For African people, life is the supreme value. As such, any suffering, real or imaginative; resulting from the transgression of the taboo reduces the power against evil forces attacks. Thus, the function of the rite is to acquire and preserve the vital force.

\section{Conclusion}

This exploratory draft has allowed us to study a clinical and psychosocial victimology of rape of children and young children in an african socio-cultural era where children still remain a community property. We analyzed rapes of proximity carried out by adults whose aggressive impulses were noticed by the extent and seriousness of the genital injuries. It should be noted that the targets of these premeditated rapes for most of the cases, girls under five years old, were the victims of a probably failing heteroeroticism of perpatrators who were rarely identified. The latter's modus operandi was divided into four phases: attracting the victim, sending the victim to a place of raping, raping and releasing the victim. Psycho-traumatic disorders were noticed from both the victims and their family caregivers in the form of vicarious trauma. In addition to this trauma, the disruption of family dynamics and parental functions should lead the teams involved in the care of these victims to carry out a sound psychological assessment and then send the victims to mental health professionals.

Child abuse, including sexual violence, which appears as one of the most frequent and destructive modalities, should be considered not simply in a humanitarian and compassionate approach. They constitute a social tragedy, an archaic pathology of civilizations which must require an ethical consideration in a context of proactive policy determined by a strong clinical knowledge [1].

\section{Conflicts of Interest}

The authors declare that they have no competing interests.

\section{References}

[1] Louis Jehel, Gerard Lopez et al. Psycho-traumatologie: Evaluation, clinique, traitement.

[2] Mémoire Traumatique Impact des violences sexuelles de l'enfance à l'age adulte: synthèse du rapport d'enquete Mars 2015. https://www.memoiretraumatique.org/assets/files/V1/campagne 2015/2015-synthese-enquete-AMTV.pdf.

[3] ONUCI, HCDH. Rapport sur les viols et leur répression en Cote D' Ivoire juillet 2016. Consultable sur: file://C; /Users/hp/Documents/bibliographie\%20finale/201607-11_Rapport_viols_cote_dIvoire\%201.pdf.

[4] Chopin, J. et Beauregard, E. (2019). Lethal combinations: A conjunctive analysis of crime scene behavior associated with sexual homicide. Behavioral Sciences \& the Law, 37, 559-578. https://doi.org/10.1002/bsl.2425.

[5] Chopin, J. et Caneppele, S. (2019). Geocoding child sexual abuse: An explorative analysis on journey to crime and to victimization from french police data. Child Abuse \& Neglect, 91, 116-130. https://doi.org/10.1016/j.chiabu. 2019.03.001.

[6] Chopin, J. et Beauregard, E. (2020). Scripting extrafamilial child sexual abuse: A latent class analysis of the entire crimecommission. Child Abuse \& Neglect. Prépublication. https://doi.org/10.1016/j.chiabu.2020.104521.

[7] Lormeau B. et Rey-Salmon C. (2019). Conduite à tenir face à une suspicion d'abus sexuel chez l'enfant. La Revue du praticien; 69 (4); 407-10.

[8] Bruno Gachassin. Le développement psychosocial chez l'homme (d'après Erikson). IFAS CHU de Nice-septembre $2017 . \quad$ extranet.chu-nice.fr/Formation-Aide-SoignantNice/uploads/Extranet/smartsection/developpement_psychoso cial_mr_gachasssin.

[9] Reza A et al. Sexual violence and its health consequences for female children in Swaziland: a cluster survey study. Lancet, 2009, 373 (9679): 1966-72.

[10] Sénat session ordinaire 2018-2019. Rapport d'information. http://www.senat.fr/rap/r18-529.1/r18-529-11.pdf.

[11] Toure I., Kouame, 1994 La violence urbaine en Côte d'ivoire: le cas de la ville d'Abidjan [en ligne] in EGHOSA E., et al, urban violence in africa. IFRA, Nigéria, consulté le 12/12/2013, 176p.

[12] Robertiello G. et Terry K. J. (2007). Can we profile sex offender? A review of sex offenders typologie, Aggression and Violent behavior, 12, 508-518.

[13] Hall, R. C. W et Hall, R. C. W (2009). A profile of pedophillia: Definition, characteristics of offenders, recidivism, treatment outcomes, and forensir issues. Focus: The journal of lifelong learning in psychiatry, 7 (4), 522-537.

[14] Tourigny, M. et Baril, K (2011). Les agressions sexuelles durant l'enfance: Ampleur et facteurs de risque, dans M. Hébert, M. Cyr, et M. Tourigny (dir.,), l'agression sexuelle envers les enfants. Tome 1 (pp 7-42) Québec: presses de l'Université du Quebec. 
[15] La Fortune, D., Proulx. J, et Tourigny. M (2010). Les adultes et les adolescents auteurs d'agression sexuelle, dans Le Blanc. M. et Cusson. M (dir.) Traité criminologie empirique (4e édition) (pp 305-336). Montréal: les presses de l’Université de Montréal.

[16] Blanchette C., St-Yves M. et Proulx J. (2007). Les agresseurs sexuels: motivation, modus operandi et habitudes de vie dans M. St-Yves et M. Tanguay (dir.), psychologie de l'enquête criminelle; la recherche de la vérité (pp. 445-464) cowans ville: Editions Yvon Blais.

[17] Rossmo, K. (2000). Geographic profiling. CRC Press in Unsolved cases of sexual assault involving children: An analysis of the commission process by Julien Chopin, Éric Beauregard and Nadine Deslauriers-Varin Enquête policière et techniques d'enquête: un regard scientifique Volume 53, Number 2, 2020 Fall URI: https://id.erudit.org/iderudit/1074189ar, DOI: https://doi.org/10.7202/1074189ar.

[18] Rada, RT. (1978). Clinical aspects of the rapists. New York: Grune et Stratton.

[19] Le Goaziou V., Mucchielli L. (2010). Les viols jugés en cours d'assises: typologie et variations géographiques. Questions pénales, 4, 1-4.
[20] Groth A. N (1978) Guidelines for the assessment and management of the offender. Dans A. W. Burgess, A. N Groth, L. L Holmstrom et S. M Sgroi (dir.), sexual assault of children and adolescents (pp25-42) Lexington, M. A: Lexington Books.

[21] André McKibben. Synthèse des typologies des violeurs (in les agresseurs sexuels théorie, évaluation et traitement de Jocelyn Aubut et Coll, Ed de la cherelière, Montréal, Maloine Paris 1993).

[22] Gilbert Vila, (1998). Clinique des violences chez l'enfant. Dans Roland Coutanceau, Carole Damiani, Mathieu Lacambre: victimes et auteurs de violence sexuelle. Page 61-71, $\mathrm{m}$ ise en ligne sur caim info le 30/09/2019.

[23] Saint-Pierre F., Viau M. F. (2010) L'enfant victime d'agression sexuelle: comprendre et aider. Montréal: Editions du CHU Sainte-Justine 226p.

[24] Hébert M., Cyr et M., Tourigny M (2011) L'agression sexuelle envers les enfants: Tome 1. Québec: Presses de l'Université du Québec.

[25] Romano H. (2013) L'enfant face au traumatisme. Paris: Dumod. 184pp.

[26] Lucien Lévy-Bruhl. (225) Le surnaturel et la nature (1963): 242. 